\title{
Synthesis and Reduction of 10-Phthalimidocamphor Oxime
}

\section{Uroš Grošelj, Amalija Golobič, Jurij Svete and Sebastijan Ričko*}

\author{
Department of Organic Chemistry, Faculty of Chemistry and Chemical Technology, University of Ljubljana, \\ Večna pot 113, SI - 1000 Ljubljana, Slovenia \\ *Corresponding author: E-mail: sebastijan.ricko@fkkt.uni-lj.si \\ Tel.: +38614798606
}

Received: 24-04-2017

Dedicated to Professor Emeritus Miha Tišler, University of Ljubljana, on the occasion of his $90^{\text {th }}$ anniversary.

\begin{abstract}
10-Phthalimidocamphor oxime was prepared from easily available 10-iodocamphor in two steps. Reduction of the oxime functionality resulted in the formation of two novel polycyclic isoindolinone heterocycles, the attempted preparation of the primary amine failed. The structures of novel heterocycles were unambiguously confirmed by single crystal X-ray diffraction as well as NMR techniques.
\end{abstract}

Keywords: 10-iodocamphor, 10-phthalimidocamphor oxime, camphor derived amines, reduction

\section{Introduction}

$(1 R)-(+)$-Camphor and its enantiomer are renewable enantiomerically pure chiral pool starting materials. The unique reactivity of camphor enables its derivatization at positions 2, 3, 4, 5, 8-10, as well as selective cleavage of the C1-C2 and C2-C3 bonds (Figure 1). ${ }^{1,2}$ All of the above makes camphor a very desirable starting compound for the preparation of a wide variety of products ${ }^{3}$ ranging from natural products ${ }^{1,2}$ to chiral auxiliaries, ${ }^{4,5}$ ligands in asymmetric synthesis, ${ }^{6-10}$ organocatalysts, ${ }^{11}$ and NMR shift reagents. $^{12}$

Within our continuing study on camphor-based diamines as potential organocatalyst scaffolds, ${ }^{13-15}$ we recently reported on the synthesis of a novel type of 1,3-diamine-derived bifunctional squaramide organocatalysts A prepared from 10-iodocamphor and their application as highly efficient catalysts in Michael additions of 1,3-dicarbonyl nucleophiles to trans- $\beta$-nitrostyrenes. ${ }^{16} 10$-Iodocamphor ${ }^{17}$ has seen surprisingly limited application as the starting compound, ${ }^{18-24}$ although, it can easily be prepared in sufficient quantities from $(1 S)-(+)$-10-camphorsulfonic acid. ${ }^{16}$ Herein we report the results of the synthesis and reduction of 10-phthalimidocamphor oxime (4), which is a potential precursor for the preparation of mono-protected primary diamine camphor building block 5 .
Instead of the desired diamine 5, isoindolinone heterocycles 6 and 7 were isolated. Isoindolinone/isoindole derivatives can be found in numerous natural and pharmaceutical compounds shoving multiple biological activities (Figure 1). ${ }^{25}$

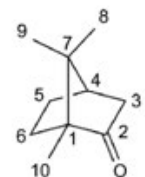

$(1 R)-(+)$-camphor

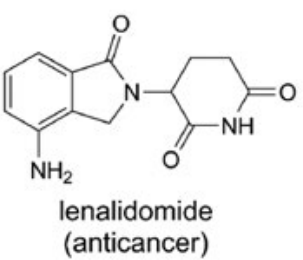<smiles>[R9]Nc1c(NC2CC3CCC2(CN2CCCC2)C3(C)C)c(=O)c1=O</smiles>

A

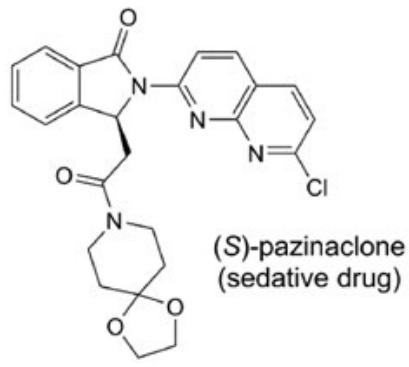




\section{Results and Discussion}

Following the literature procedure, $(1 S)-(+)-10$-camphorsulfonic acid (1) was transformed into 10-iodocamphor (2). ${ }^{16}$ The following reaction of 2 with potassium phthalimide gave the corresponding 10-phthalimidocamphor (3) in $72 \%$ yield. Finally, condensation of 3 with $\mathrm{NH}_{2} \mathrm{OH}$ furnished in $92 \%$ yield the expected 10-phthalimidocamphor oxime (4). Next, reduction of the oxime 4 was studied with the aim of preparing mono-protected primary diamine camphor building block 5 (Scheme 1).

Thus, the results of the reduction of oxime 4 are summarized in Scheme 2 and Table 1. Catalytic hydrogena- tion of $\mathbf{4}$ using $\mathrm{Pd}-\mathrm{C}$ in $\mathrm{MeOH}$ with or without $\mathrm{HCl}$ yielded only the recovered starting material (Entries 1 and 2). On the other hand, reduction of $\mathbf{4}$ with $\mathrm{Na}$ in $n-\mathrm{PrOH}$, as expected, gave a complex mixture of products (Entry 3). Catalytic hydrogenation using Raney-Ni gave the polycyclic secondary amine 6 in 37\% isolated yield (Entry 4). Clearly, the reduction of oxime 4 was successful, though the reaction did not stop at the desired diamine level $\mathbf{5}$. Therefore, the reduction with Raney-Ni was repeated in the presence of AcOH (Entry 5) and aqueous formaldehyde (Entry 6) in order to obtain either the amine 5 or a tertiary dimethylamine derivative. The former reaction again delivered compound $\mathbf{6}$ in 20\% yield, while the later

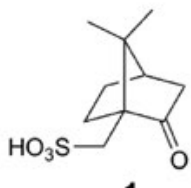

1

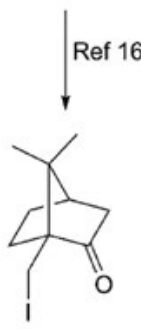

2

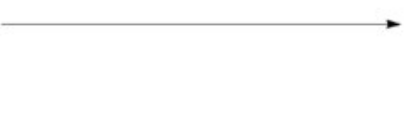
$100^{\circ} \mathrm{C}, 16 \mathrm{~h}$

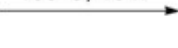

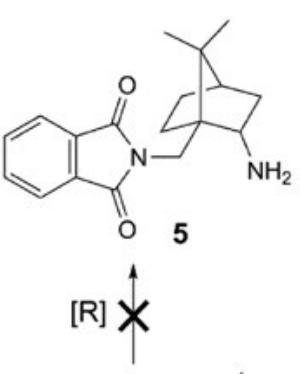

$\mathrm{NH}_{2} \mathrm{OH} \bullet \mathrm{HCl}$

pyridine $\mathrm{EtOH}, \Delta, 16 \mathrm{~h}$

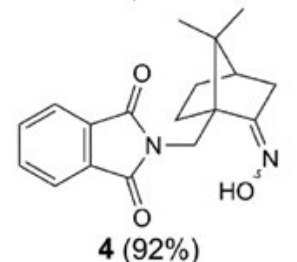

Scheme 1. Attempted synthesis of monoprotected diamine $\mathbf{5}$.

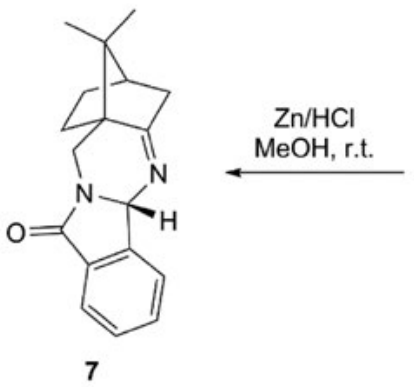

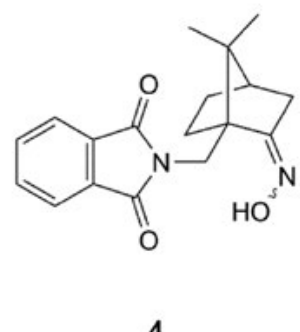

Raney-Ni $\mathrm{MeOH}$, r.t.

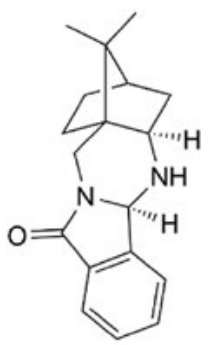

6

Scheme 2. Synthesis of amine 6 and imine 7 from oxime 4 .

Table 1. Reduction of oxime $\mathbf{4}$ under various reaction conditions.

\begin{tabular}{lccccc}
\hline Entry & Reducing agent & Solvent & $\mathbf{T}\left({ }^{\circ} \mathbf{C}\right)$ & $\mathbf{t}(\mathbf{h})$ & Product/Yield (\%) \\
\hline 1 & $\mathrm{Pd}-\mathrm{C}$ & $\mathrm{MeOH}$ & r.t. & 8 & no reaction \\
2 & $\mathrm{Pd}-\mathrm{C} / \mathrm{HCl}$ & $\mathrm{MeOH}$ & r.t. & 8 & no reaction \\
3 & $\mathrm{Na}$ & $\mathrm{n}-\mathrm{PrOH}$ & 90 & 2 & complex mixture \\
4 & Raney $-\mathrm{Ni}$ & $\mathrm{MeOH}$ & r.t. & 8 & $\mathbf{6}(37)$ \\
5 & Raney $-\mathrm{Ni} / \mathrm{AcOH}$ & $\mathrm{MeOH}$ & r.t. & 8 & $\mathbf{6}(20)$ \\
6 & Raney $-\mathrm{Ni} / \mathrm{HCHO}$ & $\mathrm{MeOH}$ & r.t. & 8 & complex mixture \\
7 & $\mathrm{Zn} / \mathrm{HCl}$ & $\mathrm{MeOH}$ & r.t. & a) & $7(45)$ \\
8 & $\mathrm{Zn}$ & $\mathrm{AcOH}$ & r.t. & a) & complex mixture \\
9 & $\mathrm{Zn} / \mathrm{HCl}$ & $\mathrm{AcOH}$ & r.t. & a) & complex mixture \\
\hline
\end{tabular}

a) Till the disappearance of the starting material (TLC analysis). 
yielded a complex mixture of products. Next, reduction of oxime 4 with $\mathrm{Zn}$ in $\mathrm{MeOH}$ in the presence of excess aqueous $\mathrm{HCl}$ was performed, furnishing imine 7 in $45 \%$ yield (Entry 7). Repeating the reduction of 4 with $\mathrm{Zn}$ in $\mathrm{AcOH}$ with or without aqueous $\mathrm{HCl}$ yielded complex mixtures of products (Entries 8 and 9).

The formation of the products 6 and 7 could be rationalized by the initial formation of the primary amine $\mathbf{5}$, followed by the condensation with the proximal carbonyl group of the phthalimide functionality to give intermediate 8 . Isomerization of $\mathbf{8}$ to imine $\mathbf{7}$ is explained by a simple imine-imine tautomerisation, while reduction (or isomerization/reduction) of 8 would lead to amine $\mathbf{6}$ (Scheme $3)$. The configuration of the newly formed stereogenic centers seems to be dictated by the reducing agent applied.

\section{1. Crystal Structures of Compounds 6 and 7}

The asymmetric units of compounds 6 and 7 are depicted in Figures 2 and 3, respectively. In both structures there is one molecule in the asymmetric unit. Bond lengths are given in Table 2. Most of bond lengths are very similar both in 6 and 7, with the exception of bonds including atoms $\mathrm{N} 2$ and C9. This is in accordance with their structural chemical formulas (as shown in Scheme 2) which differ only in the closeness of these two atoms. Bond N2-C9 in 6, 1.463(3) $\AA$, is significantly longer than $1.265(2) \AA ̊$ in 7, which is in accordance with the fact that this is a single bond in $\mathbf{6}$ and a double bond in 7 . The average $\mathrm{C}\left(s p^{3}\right)-\mathrm{N}(3)$ single bond and $\mathrm{C}(\mathrm{sp} 2)=\mathrm{N}(2)$ double bond in the literature ${ }^{1}$ are $1.469(14)$ and $1.279(8) \AA$, respectively. Usually $\mathrm{C}\left(s p^{3}\right)-\mathrm{C}\left(s p^{3}\right)$ bond distances are longer in comparison to $\mathrm{C}\left(s p^{3}\right)-\mathrm{C}\left(s p^{2}\right)$. In accordance to this, $\mathrm{C} 9-\mathrm{C} 10$ and $\mathrm{C} 9-\mathrm{C} 15$ are longer in 6 than in 7.

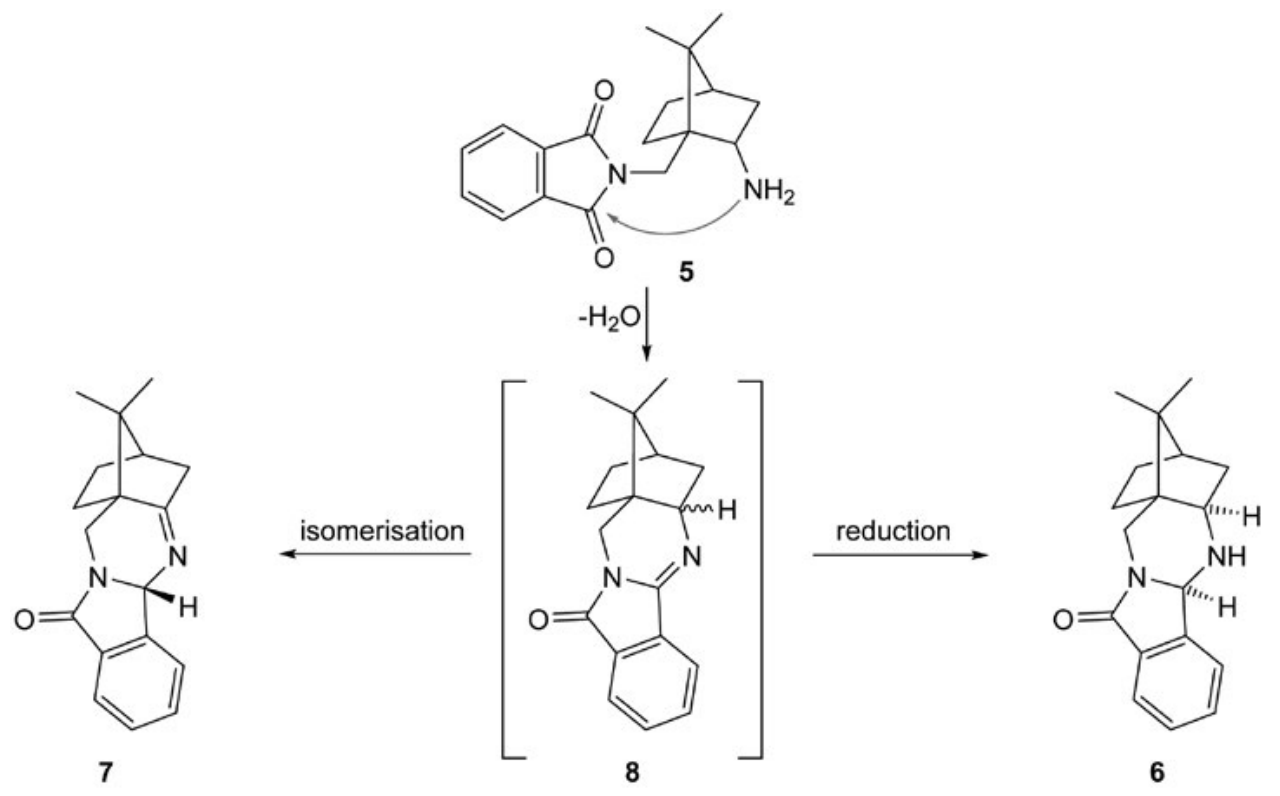

Scheme 3. Rationalization of the formation of products 6 and 7.
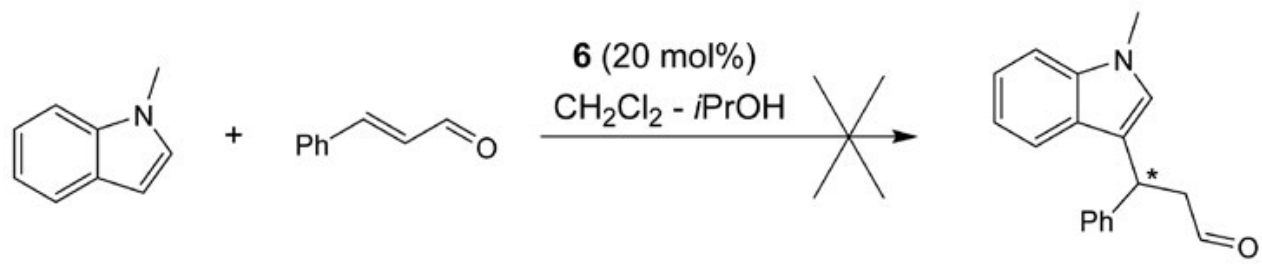

Scheme 4. Atempted addition of 1-methylindole to cinnamaldehyde catalyzed by 6 .

Compound 6 was tested as a potential covalent organocatalyst in the addition of 1-methylindole to cinnamaldehyde. ${ }^{26}$ Amine 6 failed to catalyze the reaction (Scheme 4).

The structures of novel compounds 3, 4, 6, and 7 were determined by spectroscopic methods ( ${ }^{1} \mathrm{H}-\mathrm{NMR}$, $\left.{ }^{13} \mathrm{C}-\mathrm{NMR}, \mathrm{IR}, \mathrm{HRMS}\right)$.
Molecules of $\mathbf{6}$ and $\mathbf{7}$ are asymmetric. In both structures, chiral carbon centres are C8, C10, and C14; in 6 C9 atom is also chiral. C10 and C14 from camphor part of the molecule have in both compounds absolute configuration $(S)$ and $(R)$, respectively. The absolute configuration of C8 atom from phthalimde ring is $(R)$ in $\mathbf{6}$ and $(S)$ in 7, respec- 
tively. Consequently, the conformation of molecules of $\mathbf{6}$ and $\mathbf{7}$ is different in a way how a camphor part is bonded to the remaining part of molecule which is shown in Figure 4. In accordance with their optical activity, both compounds crystalize in chiral space group. Compound $\mathbf{6}$ crystalizes in orthorhombic crystal system in $P 2_{1} 2_{1} 2_{1}$ and 7 in tetragonal $P 4_{3} 22$, respectively. The packing of molecules is presented in Figures 5 and 6. In 6 molecules are connected via $\mathrm{N} 2-\mathrm{H} \cdots \mathrm{O} 1$ hydrogen bonds into chains parallel to $b$ axis. Geometrical parameters of this $\mathrm{H}$-bond are given in Table 3. The distance between the donor, N2,

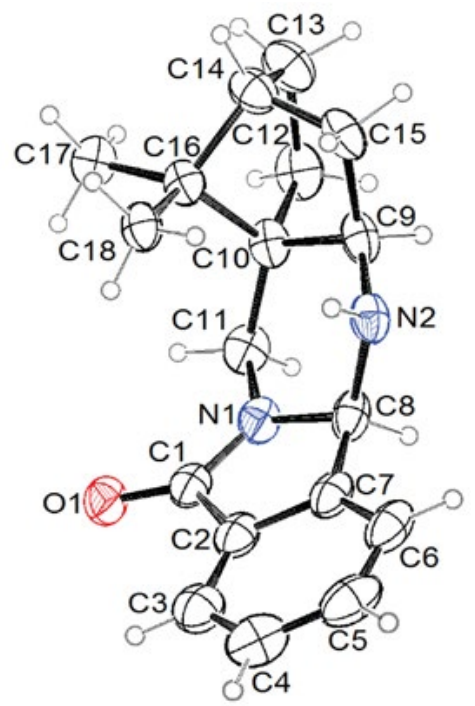

Figure 2. Ortep ${ }^{28}$ drawing of asymmetric unit of compound 6. Displacement ellipsoids are drawn with $25 \%$ probability level and the hydrogen atoms are shown as small spheres of arbitrary radii.
Table 2. Bond lengths in 6 and $7(\AA)$.

\begin{tabular}{lcc}
\hline bond & $\mathbf{6}$ & $\mathbf{7}$ \\
\hline O1-C1 & $1.230(2)$ & $1.222(1)$ \\
N1-C1 & $1.347(3)$ & $1.356(2)$ \\
N1-C8 & $1.466(3)$ & $1.460(2)$ \\
N1-C11 & $1.453(3)$ & $1.451(2)$ \\
N2-C8 & $\mathbf{1 . 4 3 8 ( 2 )}$ & $\mathbf{1 . 4 6 4 ( 2 )}$ \\
N2-C9 & $\mathbf{1 . 4 6 3 ( 3 )}$ & $\mathbf{1 . 2 6 5 ( 2 )}$ \\
C1-C2 & $1.490(3)$ & $1.493(2)$ \\
C2-C7 & $1.381(3)$ & $1.379(2)$ \\
C2-C3 & $1.377(3)$ & $1.384(2)$ \\
C3-C4 & $1.375(4)$ & $1.387(2)$ \\
C4-C5 & $1.373(5)$ & $1.385(2)$ \\
C5-C6 & $1.389(4)$ & $1.381(2)$ \\
C6-C7 & $1.387(3)$ & $1.383(2)$ \\
C7-C8 & $1.504(3)$ & $1.502(2)$ \\
C9-C10 & $\mathbf{1 . 5 1 9 ( 2 )}$ \\
C9-C15 & $\mathbf{1 . 5 6 5 ( 3 )}$ & $\mathbf{1 . 5 2 2 ( 2 )}$ \\
C10-C11 & $1.519(1)$ \\
C10-C12 & $1.546(3)$ & $1.550(2)$ \\
C10-C16 & $1.521(3)$ & $1.553(2)$ \\
C12-C13 & $1.551(3)$ & $1.556(2)$ \\
C13-C14 & $1.557(3)$ & $1.523(2)$ \\
C14-C15 & $1.540(3)$ & $1.536(2)$ \\
C14-C16 & $1.531(3)$ & $1.554(2)$ \\
C16-C17 & $1.531(2)$ \\
C16-C18 & $1.551(3)$ & $1.528(2)$ \\
\hline
\end{tabular}

and acceptor, $\mathrm{O} 1$, is not short, which means that $\mathrm{H}$-bond is weak. In 7 there are no $\mathrm{N}-\mathrm{H}$ or $\mathrm{O}-\mathrm{H}$ groups and consequently no classical intermolecular $\mathrm{H}$-bonds. $\mathrm{N}$ and $\mathrm{O}$ atoms are acceptors of weak intermolecular H-bonds, donated by $\mathrm{C}-\mathrm{H}$ moieties and presented in Table 3. In 6 and 7

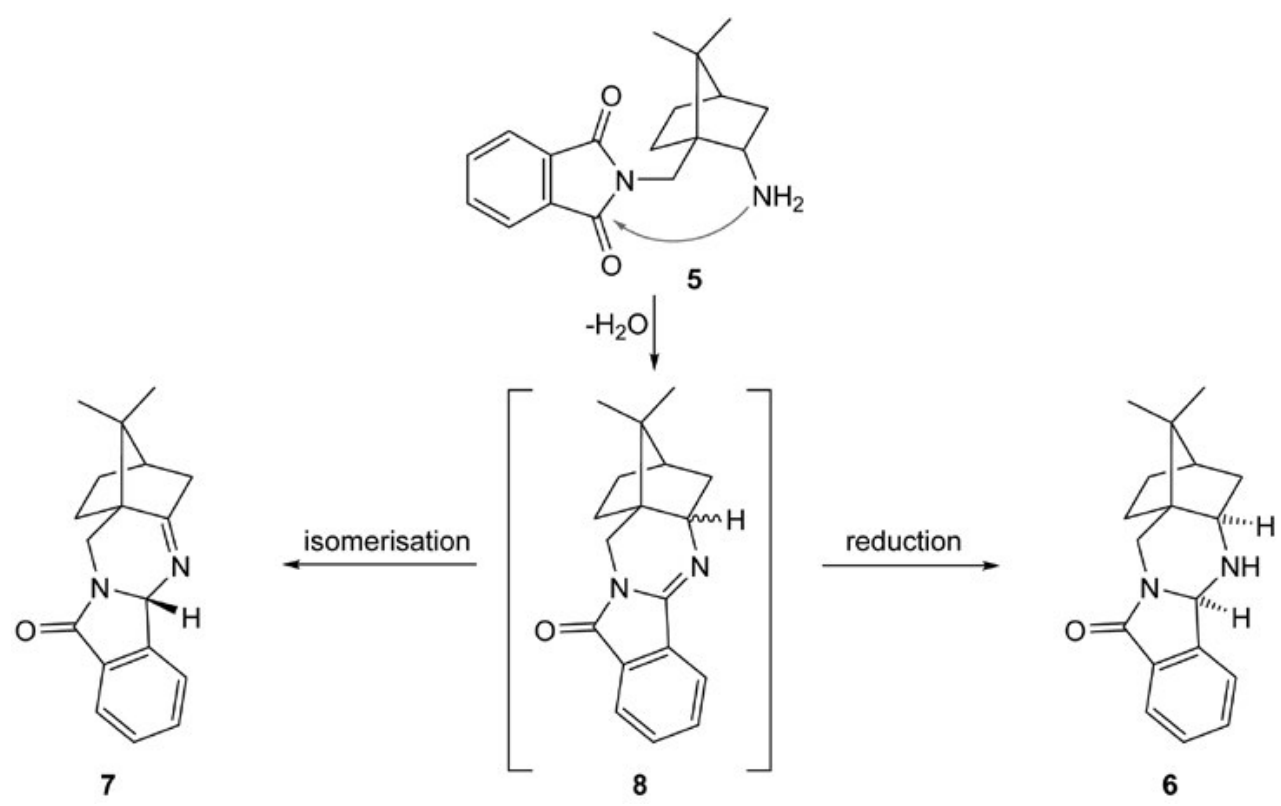

Figure 3. Orte ${ }^{28}$ drawing of asymmetric unit of compound 7. Displacement ellipsoids are drawn with $25 \%$ probability level and the hydrogen atoms are shown as small spheres of arbitrary radii. 


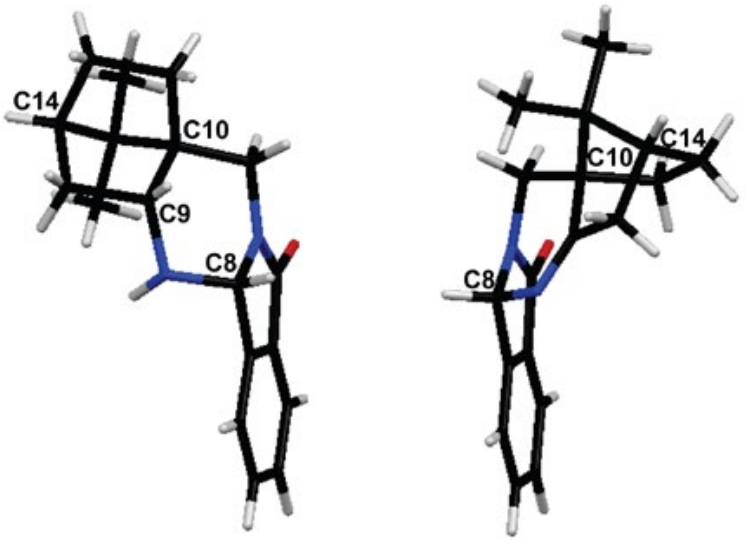

Figure 4. Mercury ${ }^{29}$ drawing of compounds 6 (on left) and 7 (on right) with labelling of chiral carbon centers of the phthalimide part of the molecule.

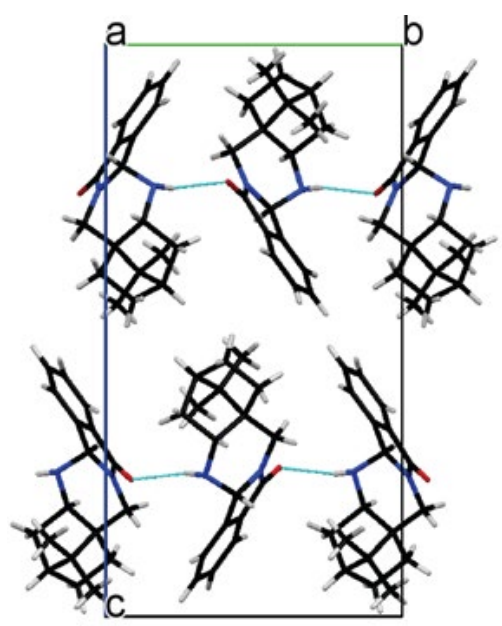

Figure 5. Mercury ${ }^{29}$ drawing of molecular packing in 6. Light blue lines show intermolecular N-H...O hydrogen bonds. there are no $\pi \cdots \pi$ or $\pi \cdots \sigma$ stacking interaction between aromatic rings.

\section{Conclusion}

The title 10-phthalimidocamphor oxime (4) was prepared as a precursor for the preparation of monoprotected camphor derived 1,3-diamine building block 5 . Reduction thereof under various reaction conditions could never be stopped at the diamine 5 level, instead polycyclic isoindolinone heterocycles 6 and 7 were isolated. The structures of $\mathbf{6}$ and $\mathbf{7}$ were confirmed by X-ray analysis of the corresponding monocrystals.

\section{Experimental Section}

Solvents for extractions and chromatography were of technical grade and were distilled prior to use. Extracts were dried over technical grade $\mathrm{Na}_{2} \mathrm{SO}_{4}$. Melting points were determined on a Kofler micro hot stage and on SRS OptiMelt MPA100 - Automated Melting Point System (Stanford Research Systems, Sunnyvale, California, United States). The NMR spectra were obtained on a Bruker UltraShield 500 plus (Bruker, Billerica, Massachusetts, United States) at $500 \mathrm{MHz}$ for ${ }^{1} \mathrm{H}$ and $126 \mathrm{MHz}$ for ${ }^{13} \mathrm{C}$ nucleus, using DMSO- $d_{6}$ and $\mathrm{CDCl}_{3}$ with TMS as the internal standard, as solvents. Mass spectra were recorded on an Agilent 6224 Accurate Mass TOF LC/MS (Agilent Technologies, Santa Clara, California, United States), IR spectra on a Perkin-Elmer Spectrum BX FTIR spectrophotometer (PerkinElmer, Waltham, Massachusetts, United States). Catalytic hydrogenation was performed on a Parr Pressure Reaction Hydrogenation Apparatus (Moline, IL, USA).

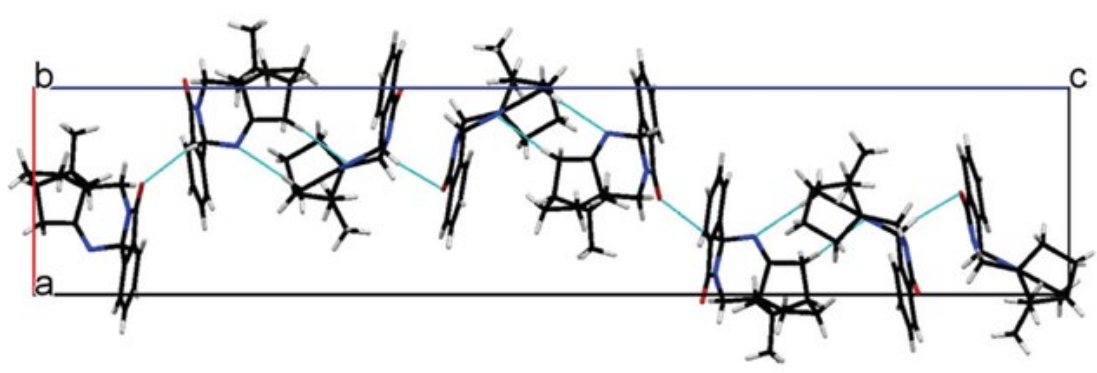

Figure 6. Mercury ${ }^{29}$ drawing of molecular packing in 7. Light blue lines show weak intermolecular C-H...O and C-H...N hydrogen bonds.

Table 3. Hydrogen-bond geometry in 6 and $7\left(\AA,^{\circ}\right)$.

\begin{tabular}{lllll}
\hline $\mathrm{D}-\mathrm{H} \cdots \mathrm{A}$ & $\mathrm{D}-\mathrm{H}$ & $\mathrm{H} \cdots \mathrm{A}$ & $\mathrm{D} \cdots \mathrm{A}$ & $\mathrm{D}-\mathrm{H} \cdots \mathrm{A}$ \\
$\mathrm{N} 2-\mathrm{H} 2^{\prime} \cdots \mathrm{O} 1 \mathrm{i}$ & $0.91(2)$ & $2.25(2)$ & $3.127(2)$ & $161(2)$ \\
$\mathrm{C} 8-\mathrm{H} \cdots \mathrm{O} 1 \mathrm{ii}$ & 0.98 & 2.57 & $3.509(2)$ & 162 \\
$\mathrm{C} 15-\mathrm{H} \cdots \mathrm{N} 2 \mathrm{iii}$ & 0.97 & 2.69 & $3.654(2)$ & 173 \\
\hline
\end{tabular}

Symmetry codes: (i) $-x, y+1 / 2,-z+1 / 2$, (ii) $1 / 2+x, 3 / 2-y, 1 / 4-z$, (iii) $y, x,-z$.
Column chromatography (CC) was performed on silica gel (Silica gel 60, particle size: $0.035-0.070 \mathrm{~mm}$ (Sigma-Aldrich, St. Louis, Missouri, United States)).

Synthesis of 2-(((1R,4R)-7,7-dimethyl-2-oxobicyclo[2.2.1] heptan-1-yl)methyl)isoindoline-1,3-dione (3).

To a suspension of 10-iodocamphor (2) $(420 \mathrm{mg}$, $1.51 \mathrm{mmol})$ in anhydrous DMSO $(10 \mathrm{~mL})$ under argon 
potassium phthalimide ( $524 \mathrm{mg}, 2.83 \mathrm{mmol}$ ) was added and the resulting reaction mixture was heated at $100{ }^{\circ} \mathrm{C}$ under argon for $16 \mathrm{~h}$. Volatile components were evaporated in vacuo. The residue was suspended in $\mathrm{H}_{2} \mathrm{O}(20 \mathrm{~mL})$ and extracted with EtOAc $(3 \times 40 \mathrm{~mL})$. The combined organic phase was washed with $\mathrm{H}_{2} \mathrm{O}(20 \mathrm{~mL})$ and $\mathrm{NaCl}$ (aq. sat., $20 \mathrm{~mL}$ ), dried over anhydrous $\mathrm{Na}_{2} \mathrm{SO}_{4}$, filtered, and volatile components evaporated in vacuo. The residue was purified by column chromatography (EtOAc:petroleum ether $=1: 2$ ). Fractions containing the pure product 3 were combined and volatile components evaporated in vacuo. Yield: $320 \mathrm{mg}$ (1.076 mmol, 72\%) of white solid; mp 123$129^{\circ} \mathrm{C}$. $[\alpha]_{\mathrm{D}}^{\text {r.t. }}=-2.4\left(\mathrm{c}=0.25, \mathrm{CH}_{2} \mathrm{Cl}_{2}\right)$. EI-HRMS: $m / z=$ $298.1437\left(\mathrm{MH}^{+}\right) ; \mathrm{C}_{18} \mathrm{H}_{20} \mathrm{NO}_{3}$ requires: $m / z=298.1438$ $\left(\mathrm{MH}^{+}\right) ; v_{\max } 3469,3189,3066,2959,2888,1773,1731$, $1712,1604,1466,1426,1398,1373,1361,1309,1295$, $1191,1157,1142,1106,1089,1053,1031,1008,935,872$, 763, 712, 642, $625 \mathrm{~cm}^{-1} .{ }^{1} \mathrm{H}-\mathrm{NMR}\left(500 \mathrm{MHz}, \mathrm{CDCl}_{3}\right): \delta$ $0.95(s, 3 \mathrm{H}, \mathrm{Me}) ; 1.10(s, 3 \mathrm{H}, \mathrm{Me}) ; 1.30-1.37(m, 1 \mathrm{H})$; $1.52-1.60(m, 1 \mathrm{H}) ; 1.88(d, J=18.3 \mathrm{~Hz}, 1 \mathrm{H}) ; 1.84-1.99$ $(m, 2 \mathrm{H}) ; 2.01(t, J=4.5 \mathrm{~Hz}, 1 \mathrm{H}) ; 2.43(d d d, J=2.5 ; 4.9$; $18.4 \mathrm{~Hz}, 1 \mathrm{H}) ; 3.77(d, J=14.9 \mathrm{~Hz}, 1 \mathrm{H}) ; 4.07(d, J=14.9$ $\mathrm{Hz}, 1 \mathrm{H}) ; 7.72(d d, J=3.0 ; 5.5 \mathrm{~Hz}, 2 \mathrm{H}$ of $\mathrm{Ar}) ; 7.85(d d, J=$ 3.1; $5.4 \mathrm{~Hz}, 2 \mathrm{H}$ of Ar). ${ }^{13} \mathrm{C}-\mathrm{NMR}\left(126 \mathrm{MHz}, \mathrm{CDCl}_{3}\right): \delta$ 19.5, 19.7, 26.7, 26.7, 34.7, 43.3, 43.5, 47.2, 61.1, 123.4, $132.2,134.1,168.9,216.7$.

Synthesis of 2-(( $1 R, 4 R)-2$-(hydroxyimino)-7,7-dimethylbicyclo[2.2.1] heptan-1-yl)methyl)isoindoline-1,3-dione (4).

To a solution of ketone $3(2.76 \mathrm{~g}, 9.28 \mathrm{mmol})$ in $\mathrm{EtOH}(45 \mathrm{~mL}) \mathrm{NH}_{2} \mathrm{OH} \cdot \mathrm{HCl}(1.30 \mathrm{~g}, 18.7 \mathrm{mmol})$ and pyridine $(1.10 \mathrm{~g}, 13.9 \mathrm{mmol})$ were added and the resulting reaction mixture was heated under reflux for $16 \mathrm{~h}$. Volatile components were evaporated in vacuo, followed by the addition of $\mathrm{H}_{2} \mathrm{O}(25 \mathrm{~mL})$ and finely powdered $\mathrm{NaOH}$ till the $\mathrm{pH} \sim 10-12$. The resulting mixture was extracted with $\mathrm{Et}_{2} \mathrm{O}(5 \times 40 \mathrm{~mL})$. The combined organic phase was washed with $\mathrm{H}_{2} \mathrm{O}(5 \mathrm{~mL})$ and $\mathrm{NaCl}$ (aq. sat., $5 \mathrm{~mL}$ ), dried over anhydrous $\mathrm{Na}_{2} \mathrm{SO}_{4}$, filtered, and volatile components evaporated in vacuo. The residue was purified by column chromatography (EtOAc:petroleum ether $=1: 2$ ). Fractions containing the pure product 4 were combined and volatile components evaporated in vacuo. Yield: $2.67 \mathrm{~g}(8.54 \mathrm{mmol}$, 92\%) of white solid; $\mathrm{mp} 151-155^{\circ} \mathrm{C} .[\alpha]_{\mathrm{D}}^{\text {r.t. }}=-50.6(\mathrm{c}=$ 0.33, $\left.\mathrm{CH}_{2} \mathrm{Cl}_{2}\right)$. EI-HRMS: $m / z=313.1547\left(\mathrm{MH}^{+}\right) ; \mathrm{C}_{18} \mathrm{H}-$ ${ }_{21} \mathrm{~N}_{2} \mathrm{O}_{3}$ requires: $m / z=313.1547\left(\mathrm{MH}^{+}\right) ; v_{\max } 3469,3280$, $2945,2881,1774,1713,1612,1467,1427,1395,1387,1362$, $1338,1312,1297,1245,1197,1158,1104,1028,1015,987$, 962, 927, 913, 875, 855, 821, 800, 717, $611 \mathrm{~cm}^{-1} .{ }^{1} \mathrm{H}-\mathrm{NMR}$ $\left(500 \mathrm{MHz}, \mathrm{CDCl}_{3}\right): \delta 0.90(s, 3 \mathrm{H}, \mathrm{Me}) ; 1.07(s, 3 \mathrm{H}, \mathrm{Me})$; $1.20-1.28(m, 1 \mathrm{H}) ; 1.58-1.65(m, 1 \mathrm{H}) ; 1.76-1.85(m, 2 \mathrm{H})$; $1.95-2.03(m, 1 \mathrm{H}) ; 2.08(d, J=17.8 \mathrm{~Hz}, 1 \mathrm{H}) ; 2.59(d t, J=$ $3.8 ; 17.9 \mathrm{~Hz}, 1 \mathrm{H}) ; 3.88(d, J=14.7 \mathrm{~Hz}, 1 \mathrm{H}) ; 4.10(d, J=14.8$ $\mathrm{Hz}, 1 \mathrm{H}) ; 7.63(\mathrm{br} s, 1 \mathrm{H}) ; 7.72(d d, J=3.0 ; 5.5 \mathrm{~Hz}, 2 \mathrm{H}$ of Ar); $7.85\left(d d, J=3.1 ; 5.4 \mathrm{~Hz}, 2 \mathrm{H}\right.$ of Ar). ${ }^{13} \mathrm{C}-\mathrm{NMR}(126 \mathrm{MHz}$,
$\left.\mathrm{CDCl}_{3}\right): \delta 19.2,19.3,27.0,29.5,32.9,35.8,44.6,48.7,55.5$, $123.4,132.2,134.1,168.5,169.1$.

Synthesis of $(4 \mathrm{~b} R, 5 \mathrm{a} R, 7 R, 9 \mathrm{a} S)-13,13-d i m e t h y l-5,5 \mathrm{a}, 6$, 7,8,9-hexahydro-10H-7,9a-methanoisoindolo[1,2-b] quinazolin-12(4bH)-one (6).

A mixture of compound $4(246 \mathrm{~g}, 0.788 \mathrm{mmol})$, $\mathrm{MeOH}(50 \mathrm{~mL})$, and Raney-Ni $(100 \mathrm{mg})$ was hydrogenated $\left(4 \mathrm{bar}\right.$ of $\left.\mathrm{H}_{2}\right)$ at room temperature for $8 \mathrm{~h}$. The reaction mixture was filtered through a short pad of Celite ${ }^{\circledR}$, washed with $\mathrm{MeOH}(20 \mathrm{~mL})$, and the filtrate evaporated in vacuo. The residue was purified by column chromatography ( 1 . $n$-hexane: $\mathrm{Et}_{2} \mathrm{O}=1: 3$ to elute the nonpolar impurities; 2 . $\mathrm{Et}_{3} \mathrm{~N}: \mathrm{Et}_{2} \mathrm{O}=1: 40$ to elute the product 6). Fractions containing the pure product $\mathbf{6}$ were combined and volatile components evaporated in vacuo. Yield: $83 \mathrm{mg}(0.294$ mmol, $37 \%)$ of white solid; $\mathrm{mp} 154-158^{\circ} \mathrm{C}$. $[\alpha]_{\mathrm{D}}{ }_{\mathrm{r}}^{\text {r.t. }}=-163.0$ $\left(c=0.40, \mathrm{CH}_{2} \mathrm{Cl}_{2}\right)$. EI-HRMS: $m / z=283.1801\left(\mathrm{MH}^{+}\right)$; $\mathrm{C}_{18} \mathrm{H}_{23} \mathrm{~N}_{2} \mathrm{O}$ requires: $m / z=283.1805\left(\mathrm{MH}^{+}\right) ; v_{\max } 3326$, $2941,2881,1672,1485,1460,1431,1388,1368,1356,1331$, $1300,1276,1263,1243,1192,1153,1130,1112,1087,1053$, 1013, 976, 948, 931, 898, 875, 846, 816, 793, 740, 708, 687, $675 \mathrm{~cm}^{-1} .{ }^{1} \mathrm{H}-\mathrm{NMR}\left(500 \mathrm{MHz}, \mathrm{CDCl}_{3}\right): \delta 0.87(s, 3 \mathrm{H}, \mathrm{Me})$; $0.99(s, 3 \mathrm{H}, \mathrm{Me}) ; 1.07-1.19(m, 2 \mathrm{H}) ; 1.19-1.24(m, 1 \mathrm{H})$; $1.51-1.58(m, 1 \mathrm{H}) ; 1.59-1.67(m, 1 \mathrm{H}) ; 1.72-1.81(m, 2 \mathrm{H})$; $1.95(d d, J=8.9 ; 13.5 \mathrm{~Hz}, 1 \mathrm{H}) ; 3.18(d, J=14.3 \mathrm{~Hz}, 1 \mathrm{H})$; $3.25(d d, J=4.6 ; 8.9 \mathrm{~Hz}, 1 \mathrm{H}) ; 4.44(d, J=14.4 \mathrm{~Hz}, 1 \mathrm{H}) ; 5.12$ $(s, 1 \mathrm{H}) ; 7.47-7.60(m, 3 \mathrm{H}, 3 \mathrm{H}$ of $\mathrm{Ar}) ; 7.81-7.86(m, 1 \mathrm{H}, 1 \mathrm{H}$ of Ar). ${ }^{13} \mathrm{C}$-NMR $\left(126 \mathrm{MHz}, \mathrm{CDCl}_{3}\right): \delta 21.2,21.7,26.9$, $33.9,37.9,38.5,44.1,45.1,46.4,62.9,70.6,123.1,123.8$, $129.6,131.7,133.2,142.8,165.4$.

Synthesis of (4bS,7R,9aS)-13,13-dimethyl-6,7,8,9-tetrahydro-10H-7,9a-methanoisoindolo[ $[1,2-b]$ quinazolin$12(4 \mathrm{bH})$-one $(7)$.

To a solution of $4(113 \mathrm{mg}, 0.362 \mathrm{mmol})$ in $\mathrm{MeOH}$ $(10 \mathrm{~mL}$ ) at room temperature $\mathrm{HCl}$ (aq. $12 \mathrm{M}, 1 \mathrm{~mL}$ ) was added. Next, at room temperature under vigorous stirring, $\mathrm{Zn}$ dust (100 mg, $1.53 \mathrm{mmol}$ ) was added. After the disappearance of the starting material (TLC analysis), the reaction mixture was filtered and the filtrate evaporated in vac$u o$. The residue was suspended in $\mathrm{H}_{2} \mathrm{O}(10 \mathrm{~mL})$, finely powdered $\mathrm{NaOH}$ was added till the $\mathrm{pH} \sim 10-12$ followed by extraction with $\mathrm{Et}_{2} \mathrm{O}(3 \times 30 \mathrm{~mL})$. The combined organic phase was washed with $\mathrm{H}_{2} \mathrm{O}(10 \mathrm{~mL})$ and $\mathrm{NaCl}$ (aq. sat., 10 $\mathrm{mL}$ ), dried over anhydrous $\mathrm{Na}_{2} \mathrm{SO}_{4}$, filtered, and volatile components evaporated in vacuo. The residue was purified by column chromatography ( 1 . $n$-hexane: $\mathrm{Et}_{2} \mathrm{O}=1: 3$ to elute the nonpolar impurities; 2 . $\mathrm{Et}_{3} \mathrm{~N}: \mathrm{Et}_{2} \mathrm{O}=1: 25$ to elute the product 7). Fractions containing the pure product 7 were combined and volatile components evaporated in vacuo. Yield: $46 \mathrm{mg}(0.163 \mathrm{mmol}, 45 \%)$ of white solid; $\mathrm{mp}$ $164-172{ }^{\circ} \mathrm{C} .[\alpha]_{\mathrm{D}}^{\text {r.t. }}=+102.5\left(\mathrm{c}=0.33, \mathrm{CH}_{2} \mathrm{Cl}_{2}\right)$. EI-HRMS: $m / z=281.1646\left(\mathrm{MH}^{+}\right) ; \mathrm{C}_{18} \mathrm{H}_{21} \mathrm{~N}_{2} \mathrm{O}$ requires: $\mathrm{m} / z=281.1648$ $\left(\mathrm{MH}^{+}\right) ; v_{\max } 2951,2930,2869,1677,1615,1468,1447,1412$, $1310,1281,1225,1152,1102,1057,1025,975,320,795$, 
747, 709, 691, $621 \mathrm{~cm}^{-1} .{ }^{1} \mathrm{H}-\mathrm{NMR}\left(500 \mathrm{MHz}, \mathrm{CDCl}_{3}\right): \delta$ $1.02(s, 3 \mathrm{H}, \mathrm{Me}) ; 1.04(s, 3 \mathrm{H}, \mathrm{Me}) ; 1.18-1.27(m, 1 \mathrm{H}) ; 1.32-$ $1.39(m, 1 \mathrm{H}) ; 1.82-1.97(m, 4 \mathrm{H}) ; 2.57-2.65(m, 1 \mathrm{H}) ; 3.24$ $(d, J=13.3,1 \mathrm{H}) ; 4.43(d, J=13.3 \mathrm{~Hz}, 1 \mathrm{H}) ; 5.83-5.86(m$, $1 \mathrm{H}) ; 7.48-7.53(m, 1 \mathrm{H}, 1 \mathrm{H}$ of $\mathrm{Ar}) ; 7.58-7.63(m, 1 \mathrm{H}, 1 \mathrm{H}$ of Ar); 7.77-7.84 ( $m, 2 \mathrm{H}, 2 \mathrm{H}$ of Ar). ${ }^{13} \mathrm{C}-\mathrm{NMR}(126 \mathrm{MHz}$, $\left.\mathrm{CDCl}_{3}\right): \delta 18.6,20.0,26.9,30.0,38.3,39.6,43.3,47.1,53.0$, 73.8, 123.4, 123.5, 129.1, 131.5, 132.1, 143.4, 167.6, 180.4 .

\section{1. Single Crystal X-ray Structure Analysis of Compounds 6 and 7}

Single crystal X-ray diffraction data of compounds 6 and 7 have been collected on an Agilent SuperNova dual source diffractometer with an Atlas detector with $\mathrm{CuKa}$ radiation $(1.54184 \AA$ ) at room temperature. The diffraction data were processed using CrysAlis PRO software. ${ }^{30}$ Structure of both compounds was solved by direct methods, using SIR97. ${ }^{31}$ A full-matrix least-squares refinement on $\mathrm{F}^{2}$ was employed with anisotropic displacement parameters for all non-hydrogen atoms. $\mathrm{H}$ atoms were placed at calculated positions and treated as riding. For $\mathrm{H}$ atoms from methyl groups, torsion angles were calculated from electron density. Only $\mathrm{H}$ atom bonded to $\mathrm{N} 2$, was located from difference Fourier map and refined with isotropic displacement parameter. The absolute structure of both compounds was confirmed also by the refinement of Flack parameter. SHELXL97 software ${ }^{32}$ was used for structure refinement and interpretation. Drawings of the structures were produced using ORTEP- $3^{28}$ and Mercury ${ }^{29}$. Structural and other crystallographic details on data collection and refinement have been deposited with the Cambridge Crystallographic Data Centre as supplementary publication numbers CCDC 1539864-1539865, for 6 and 7, respectively. These data can be obtained free of charge via www.ccdc. cam.ac.uk/conts/retrieving.html (or from the CCDC, 12 Union Road, Cambridge CB2 1EZ, UK; fax: 441223 336033; e-mail: deposit@ccdc.cam.ac.uk).

\section{Acknowledgements}

The authors acknowledge the financial support from the Slovenian Research Agency(research core funding No. P1-0179). We also thank to EN-FIST Centre of Excellence (Ljubljana, Slovenia) for using the SuperNova diffractometer.

\section{References}

1. T. Money, Remote functionalization of camphor: application to natural product synthesis. Org. Synth.: Theory Appl. 1996, $3,1-83$.

2. T. Money, Nat. Prod. Rep. 1985, 2, 253-289.

DOI:10.1039/np9850200253
3. U. Grošelj, Targets Heterocycl. Syst. 2015, 19, 62-100.

4. W. Oppolzer, Tetrahedron 1987, 43, 1969-2004.

DOI:10.1016/S0040-4020(01)86780-6

5. W. Oppolzer, Pure Appl. Chem. 1990, 62, 1241-1250.

6. S. A. Matlin, W. J. Lough, L. Chan, D. M. H. Abram, Z. Zhou, J. Chem. Soc., Chem. Commun. 1984, 1038-1040.

DOI:10.1039/C39840001038

7. C. Chapuis, J. Jurczak, Helv. Chim. Acta 1987, 70, 436-440. DOI:10.1002/hlca.19870700223

8. K. Tomioka, Synthesis 1990, 541-549. DOI:10.1055/s-1990-26935

9. R. Noyori, M. Kitamura, Angew. Chem. Int. Ed. Engl. 1991, 30, 49-69. DOI:10.1002/anie.199100491

10. H. C. Brown, P. V. Ramachandran, Pure Appl. Chem. 1991, 63, 307-16. DOI:10.1351/pac199163030307

11. U. Grošelj, Curr. Org. Chem. 2015, 19, 2048-2074. DOI:10.2174/1385272819666150713180204

12. H. L. Goering, J. N. Eikenberry, G. S. Koermer, J. Chem. Soc. 1971, 93, 5913-5914. DOI:10.1021/ja00751a065

13. U. Grošelj, A. Golobič, K. Stare, J. Svete, B. Stanovnik, Chirality 2012, 24, 307-317. DOI:10.1002/chir.21999

14. U. Grošelj, S. Ričko, J. Svete, B. Stanovnik, Chirality 2012, 24, 412-419. DOI:10.1002/chir.22035

15. S. Ričko, A. Golobič, J. Svete, B. Stanovnik, U. Grošelj, Chirality 2015, 27, 39-52. DOI:10.1002/chir.22386

16. S. Ričko, J. Svete, B. Štefane, A. Perdih, A. Golobič, A. Meden, U. Grošelj, Adv. Synth. Catal. 2016, 358, 3786-3796. DOI:10.1002/adsc.201600498

17. J. D. Loudon, J. Chem. Soc. 1933, 823-825. DOI: $10.1039 /$ jr9330000823

18. M. J. Spallek, G. Storch, O. Trapp, Eur. J. Org. Chem. 2012, 2012, 3929-3945.

19. K. Bica, G. Gmeiner, C. Reichel, B. Lendl, P. Gaertner, Synthesis 2007, 1333-1338.

20. S.-i. Watanabe, R. Hasebe, J. Ouchi, H. Nagasawa, T. Kataoka, Tetrahedron Lett. 2010, 51, 5778-5780.

DOI:10.1016/j.tetlet.2010.08.082

21. J. A. Gladysz, J. L. Hornby, J. E. Garbe, J. Org. Chem. 1978, 43, 1204-1208. DOI:10.1021/jo00400a040

22. M. C. Galan, K. Jouvin, D. Alvarez-Dorta, Carbohydr. Res. 2010, 345, 45-49. DOI:10.1016/j.carres.2009.09.034

23. J. E. H. Buston, I. Coldham, K. R. Mulholland, J. Chem. Soc., Perkin Trans. 1 1999, 2327-2334. DOI:10.1039/a903050f

24. T. Sell, S. Laschat, I. Dix, P. G. Jones, Eur. J. Org. Chem. 2000, 4119-4124. DOI:10.1002/1099-0690(200012)2000:24<4119: :AID-EJOC4119>3.0.CO;2-X

25. K. Speck, T. Magauer, Beilstein J. Org. Chem. 2013, 9, $2048-$ 2078 and references cited therein. DOI:10.3762/bjoc. 9.243

26. J. F. Austin, D. W. C. MacMillan, J. Am. Chem. Soc. 2002, 124, 1172-1173. DOI:10.1021/ja017255c

27. F. H. Allen, D. G. Watson, L. Brammer, A. G. Orpen, R. Taylor, International Tables for Crystallography (2006). Vol. C, chapter 9.5, 790-811.

28. L. J. Farrugia, J. Appl. Crystallogr. 1997, 30, 567-567. DOI:10.1107/S0021889897003117

29. C. F. Macrae, P. R. Edgington, P. McCabe, E. Pidcock, G. P. 
Shields, R. Taylor, M. Towler, J. van de Streek, J. Appl. Cryst. 2006, 39, 453. DOI:10.1107/S002188980600731X

30. Agilent Technologies. CrysAlis PRO. Version 1.171.35.11;

Agilent Technologies: Yarnton, Oxfordshire, England, (2011).

31. A. Altomare, M. C. Burla, M. Camalli, G. L. Cascarano, C.
Giacovazzo, A. Guagliardi, A. G. G. Moliterni, G. Polidori, R. Spagna, J. Appl. Crystallogr. 1999, 32, 115-119.

DOI:10.1107/S0021889898007717

32. G. M. Sheldrick, Acta Crystallogr., Sect. A 2008, A64, 112-122. DOI:10.1107/S0108767307043930

\section{Povzetek}

10-Ftalimidokafra oksim smo pripravili iz enostavno dostopne 10-jodokafre v dveh korakih. Pri redukciji oksima ni prišlo do tvorbe primarnega amina ampak sta nastala dva nova policiklična izoindolidinska heterocikla. Njuni strukturo smo nedvoumno potrdili z rentgensko strukturo in NMR tehnikami. 